\title{
Sagartia troglodytes (Anthozoa: Actiniaria) consists of two species
}

\author{
P. W. Shaw, J. A. Beardmore, J. S. Ryland \\ Marine, Environmental and Evolutionary Research Group, School of Biological Sciences, University College of Swansea, \\ Swansea SA2 8PP, United Kingdom
}

\begin{abstract}
The sagartiid sea anemone Sagartia troglodytes (Price) has usually been considered to consist of 2 morphological varieties linked by intermediate forms (and therefore presumably by interbreeding). The techniques of starch gel electrophoresis and chromosome preparation, combined with an analysis of reproductive biology, were employed to investigate populations around the SW coasts of Britain to test this assumption. Var. decorata is extremely variable both morphologically and genetically with high levels of polymorphism and heterozygosity $\left(\mathrm{P}=61 \%, \mathrm{H}_{0}=0.27\right)$. It reproduces exclusively by out-crossing, oviparous means producing maximal genotypic diversity and good gene flow between populations (Nei's Genetic Identity, $\bar{I}=0.99$ ). Var. ornata is less variable morphologically but genetically diverse ( $\left.\mathrm{P}=62 \%, \mathrm{H}_{0}=0.47\right)$ due to 'fixed heterozygosity' at some loci, which is maintained by extensive clonal reproduction within populations producing relatively low inter-population identity $(\bar{I}=0.86$ ). Var. decorata has a chromosome number of approximately 24 whereas var. ornata has approximately 48 . On this basis it is proposed that var.decorata should retain the species name $S$. troglodytes (Price) and that var. ornata be restored to species status as Sagartia ornata (Holdsworth, in Gosse 1860).
\end{abstract}

\section{INTRODUCTION}

Sagartia troglodytes (Price) is a widespread, if not prolific, sea anemone. Geographically it ranges from the northern Mediterranean, through the north-east Atlantic coasts of Europe into the Baltic Sea. Its habitat ranges from moderately exposed rocky to extremely sheltered sedimentary environments, both inter-tidal and sub-tidal, and includes brackish localities (Gosse 1860, Stephenson 1935, Schmidt 1972, Manuel 1981).

The species exhibits extreme phenotypic diversity of tentacle and oral disc colour and pattern. Two distinct forms of varietal status have, however, been recognised. Var. decorata exhibits considerable variation, and individuals may grow up to $50 \mathrm{~mm}$ diameter across the pedal disc and possess up to 6 cycles of tentacles (192 in total). Var. ornata shows less variation, individuals usually being of drab coloration and never exceeding $15 \mathrm{~mm}$ pedal disc diameter or having more than 5 cycles of tentacles (96 in total) (Manuel 1981).

Previous reports on the reproductive biology of this species describe it as either hermaphrodite and habitually viviparous (Gosse 1860, Stephenson 1935, Manuel 1981) or oviparous with a 1 to $2 \mathrm{wk}$ free-swimming larval phase (Carlgren in Stephenson 1935, Nyholm 1943,
Riemann-Zürneck 1969, Schmidt 1972), although no detailed information of reproductive cycles is available.

The present study was undertaken to provide information on the reproductive biology and population genetics of the species, and to elucidate the status of the 2 varieties in the light of these data.

\section{MATERIALS AND METHODS}

The population structure and genetics of 10 populations around the southwest coasts of Britain (Fig. 1) were examined by the technique of starch gel electrophoresis. Four populations consisted exclusively of var. decorata (Mumbles, University, Oxwich and Rhossili), 4 exclusively of var. ornata (Fishguard, Fleet, Weston and Bolt Head), and 2 of both varieties in sympatry (Burry Holms and Dartmouth). At each locality specimens were collected from as large an area as possible in an attempt to avoid multiple samples from possible localised clones. Individuals collected from each population were returned to the laboratory for identification of their variety, examined for the presence of brooded young, and approximately $0.125 \mathrm{~cm}^{3}$ samples of foot tissue removed and stored in $100 \mu \mathrm{l}$ of buffer $(0.02 \mathrm{M}$ Tris $/ \mathrm{HCl}, \mathrm{pH} 8.0)$ at $-70^{\circ} \mathrm{C}$. Any 


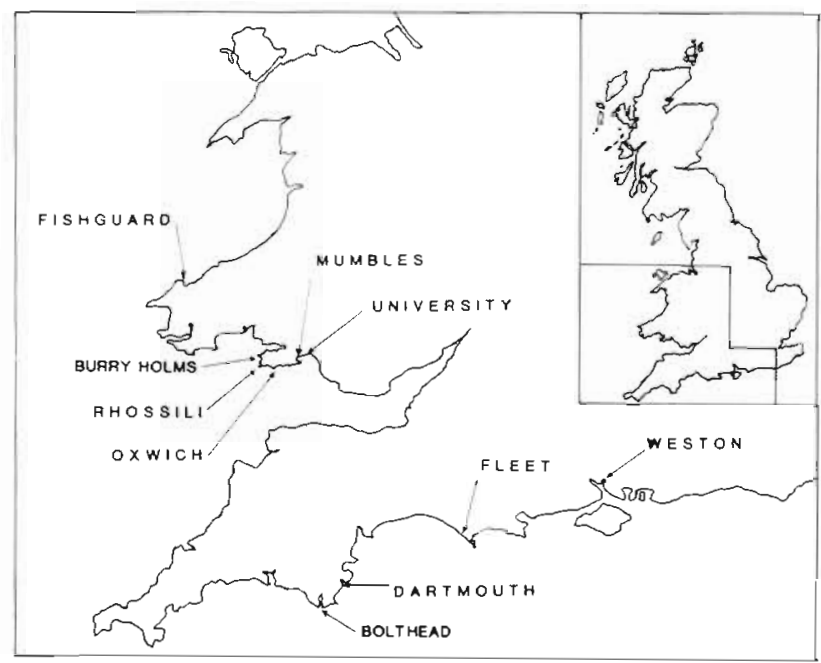

Fig. 1. Locations of sampled populations of Sagartia troglodytes on the coasts of SW Britain

brooded young found were similarly stored individually, together with a sample from the brooding adult.

Soluble extracts from the samples were analysed for enzyme variability by standard horizontal starch gel electrophoretic techniques after Harris \& Hopkinson (1976), staining procedures being modified from Shaw \& Prasad (1970) and Harris \& Hopkinson (1976), except for octopine dehydrogenase which was modified from Bucklin \& Hedgecock (1982). Buffer systems used were a discontinuous Tris-citrate/borate $\mathrm{pH}$ 8.2/8.7 (Poulik 1957) and a continuous Tris-citrate $\mathrm{pH} 7.1$ (modified from Ayala et al. 1973). Thirty-four enzymes were surveyed, of which 12 (encoded by 14 loci) were consistently resolvable and interpretable for all individuals: malic enzyme (ME); malate dehydrogenase $\left(\mathrm{MDH}_{1} 2\right.$ loci); isocitrate dehydrogenase (IDH); 6-phosphogluconate dehydrogenase (6PGDH); phosphoglucomutase (PGM); phosphoglucose isomerase (PGI); esterase (EST); octopine dehydrogenase $(\mathrm{OCDH})$; leucine amino-peptidase (LAP); hexokinase (HK); superoxide dismutase (SOD, 2 loci); catalase (CAT). Allelic designations are for all loci based on an arbitrary numbering system, the most common allele in the Mumbles population being designated 10 and alleles with products more or less anodally migrating being assigned higher or lower numbers respectively. This method of designation was chosen to facilitate easier transfer of data for computing purposes.

For each population the number of different multilocus genotypes was established, and allele frequencies, nean number of alleles per locus, number of loci polymorphic (using the $95 \%$ criterion for the common allele), observed and expected mean individual heterozygosity per locus (after Nei 1978) and deviations from Hardy-Weinberg expectations at variable loci (using chi-squared tests with Levene's [1949] correction) were calculated. Additionally, values of Nei's (1972) Genetic Identity (I) between populations were calculated and a phenogram constructed using clustering determined by UPGMA (Sneath \& Sokal 1973). The BIOSYS-1 computer programm of Swofford \& Selander (1981) was utilised in the calculation of the above statistics.

Chromosome preparations were obtained using a modification of the technique described by Rahat et al. (1985) for Hydra. If released individual young are fed a day prior to their use whole in the preparation, the resulting growth will provide useful numbers of metaphase cells. Otherwise, removal and initial regeneration of small pieces of pedal disc will produce some metaphase cells for analysis. Attempts at artificial fertilisation to produce dividing embryos were unsuccessful.

The reproductive biology of the species was investigated using monthly collections of 10 to 15 individuals which were anaesthetised and examined fresh for the presence of recognisable gonad and brooded planulae or actinulae. Measurements of the 20 largest oocytes in gonad squashes were made in pre-spawning females to establish mature egg size. Longitudinal portions ('quarters') of the column were removed and fixed in seawater Bouin's fixative for histological preparation. Transverse sections of fixed material were examined, testis development being graded on an arbitrary scale as to its maturity and ovary development determined by means of oocyte size-frequency profiles, to provide detailed information on seasonal development. Collections from the Mumbles population of var. decorata were made from January 1984 to April 1986, but a suitable population of var. ornata (at Burry Holms) was not discovered until late in the study, so data are available only between January 1986 and April 1986. However this short series does span the period of maximum gonad development in var. decorata, so is useful for comparison.

\section{RESULTS}

Chromosome preparations of these species are extremely difficult to interpret due to the small size of the chromosomes ( 1 to $2 \mu \mathrm{m}$ ), the small size of the cells, and clumping of the chromosomes. However, the difference between the 2 varieties is quite striking, var. ornata consistently having twice the number of chromosomes as found in var. decorata. Two or 3 preparations were made for each individual ( 5 individuals for ornata, 2 individuals for decorata). In each preparation suitable nuclei were looked for and in total 20 nuclei in ornata and 10 nuclei in decorata preparations were scored. The range of chromosome number observed in decorata was 19 to 27 and in ornata 40 to 55. Average counts are for decorata 24 , and ornata 48 . 
No mean differences between individuals within a variety were seen.

We believe these to be the first estimates of chromosome number in actinians. It is worth noting that 2 related species, Sagartia elegans (Dalyell) and Cereus pedunculatus (Pennant), also have approximately 24 to 26 chromosomes (authors' unpubl. data).

The demonstration that one variety is tetraploid potentially complicates the analysis of electrophoretic phenotypes by the expected gene dosage effects due to the presence of 4 copies of each gene (instead of 2 in the diploid) creating the possibility of complex heterozygotes. However, as no examples of complex heterozygotes were observed, except in 3 individuals from the Bolt Head population, ornata enzyme phenotypes were described according to the standard diploid manner (Tracey et al. 1975) to allow comparison with decorata populations.

Populations of var. decorata show maximal genotypic diversity and high genetic variability (Table 1). No polymorphic loci show genotypic frequencies significantly different from Hardy-Weinberg expectations, and levels of observed and expected heterozygosity are in agreement. In contrast, populations of var. ornata show replication of some genotypes, up to the ultimate position where only one genotype is present (Fishguard), although no genotypes are common to more than one population. However, unlike other species of actinians which have been demonstrated to utilise asexual propagation of successful genotypes (Hoffiranini 1976, Shick \& Lamb 1977, Black \& Johnson 1979, Ayre 1983, Quicke \& Brace 1983), the clones are not a diverse selection of the possible genotypes from the available genetic background. All individuals in a population share the same genotype across a number of loci which include 'fixed heterozygotes', the different clones being defined by a limited number of genotypes at the remaining variable loci. Consequently this produces large deviations from Hardy-Weinberg expectations at many of the variable loci and, of course, elevated levels of observed heterozygosity. These differences between the 2 varieties are maintained where they occur together in the same locality ('mixed' populations in Table 1).

Table 2 displays allele frequencies across all loci examined for all populations assayed. It illustrates the large differences seen at particular loci between the 2 groups of populations. Of particular note are the $2 \mathrm{MDH}$ loci at which all ornata populations have fixed, or almost fixed, heterozygosity for an allele which is absent or extremely rare in the decorata populations. Transformation of the allele frequency data into measures of genetic identity between populations (Fig. 2) illustrates the following: the 6 decorata populations are closely related genetically ( $\mathrm{I}=0.96$ to 1.00 ); the 6 ornata populations are much less closely related $(I=0.75$ to 0.97$)$; the 2 groups are genetically distinct $(\bar{I}=0.70)$, using the guidelines of previous studies (Avise et al. 1975, Thorpe 1982). Fig. 2 also includes one population (from Tenby) of the closely related species Sagartia elegans for comparative purposes.

A summary of the reproductive data produced by observations on fresh individuals and histological examination of the Mumbles decorata and the Burry Holms ornata populations is presented in Table 3. A seasonal pattern of gonad development is clear and consistent in the decorata individuals over both years examined: spawning of eggs and sperm occurs during

Table 1. Sagartia troglodytes. Genetic parameters of 12 populations assayed at 14 loci. The 'd' and 'o' designations refer to the decorata and ornata components of the mixed populations

\begin{tabular}{|c|c|c|c|c|c|c|c|}
\hline \multirow[t]{2}{*}{ Population } & \multirow[t]{2}{*}{$\begin{array}{l}\text { Sample } \\
\text { size }\end{array}$} & \multirow[t]{2}{*}{$\begin{array}{l}\text { No. different } \\
\text { genotypes }\end{array}$} & \multirow[t]{2}{*}{$\begin{array}{l}\text { Mean no. al- } \\
\text { leles per locus }\end{array}$} & \multirow{2}{*}{$\begin{array}{c}\text { No. loci } \\
\text { polymorphic } \\
\text { (95\% level) }\end{array}$} & \multirow{2}{*}{$\begin{array}{c}\text { No. loci } \\
\text { deviant from } \\
\text { H-W }(p<0.01)\end{array}$} & \multicolumn{2}{|c|}{$\begin{array}{c}\text { Mean heterozygosity } \\
\text { per locus }\end{array}$} \\
\hline & & & & & & Observed & Expected \\
\hline \multicolumn{8}{|l|}{ Var. decorata } \\
\hline Mumbles & 122 & 122 & 3.6 & 9 & 0 & 0.26 & 0.29 \\
\hline University & 46 & 46 & 3.2 & 9 & 0 & 0.28 & 0.29 \\
\hline Oxwich & 52 & 52 & 3.3 & 9 & 0 & 0.28 & 0.30 \\
\hline Rhossili & 61 & 61 & 3.1 & 7 & 0 & 0.26 & 0.27 \\
\hline \multicolumn{8}{|l|}{ Var. ornata } \\
\hline Fishguard & 72 & 1 & 1.7 & 10 & 10 & 0.71 & 0.41 \\
\hline Fleet & 52 & 9 & 1.5 & 7 & 5 & 0.41 & 0.27 \\
\hline Bolt Head & 52 & 21 & 2.1 & 7 & 5 & 0.34 & 0.25 \\
\hline Weston & 24 & 11 & 2.1 & 9 & 5 & 0.47 & 0.36 \\
\hline \multicolumn{8}{|l|}{ Mixed } \\
\hline Burry Holms 'd' & 35 & 35 & 3.1 & 8 & 1 & 0.27 & 0.29 \\
\hline Burry Holms 'o' & 83 & 52 & 2.9 & 10 & 8 & 0.47 & 0.34 \\
\hline Dartmouth 'd' & 15 & 15 & 2.3 & 9 & 0 & 0.27 & 0.29 \\
\hline Dartmouth ' $O$ ' & 9 & 8 & 1.9 & 9 & 4 & 0.39 & 0.30 \\
\hline
\end{tabular}


Table 2. Allele frequencies (\%) at 14 enzyme loci across the 12 populations studied

\begin{tabular}{|c|c|c|c|c|c|c|c|c|c|c|c|c|c|c|}
\hline \multirow{2}{*}{ Locus } & \multirow{2}{*}{ Allele } & \multirow{2}{*}{$\begin{array}{l}\text { Relative } \\
\text { mobility }\end{array}$} & \multicolumn{12}{|c|}{ Population *. } \\
\hline & & & $\begin{array}{c}1 \\
(122)\end{array}$ & $\begin{array}{c}2 \\
(46)\end{array}$ & $\begin{array}{c}3 \\
(52)\end{array}$ & $\begin{array}{c}4 \\
(61)\end{array}$ & $\begin{array}{c}5 \\
(35)\end{array}$ & $\begin{array}{c}6 \\
(15)\end{array}$ & $\begin{array}{c}7 \\
(72)\end{array}$ & $\begin{array}{c}8 \\
(83)\end{array}$ & $\begin{array}{c}9 \\
(52)\end{array}$ & $\begin{array}{l}10 \\
(9)\end{array}$ & $\begin{array}{c}11 \\
(52)\end{array}$ & $\begin{array}{c}12 \\
(24)\end{array}$ \\
\hline \multirow[t]{4}{*}{$\mathrm{Me}$} & 6 & 0.77 & - & - & - & - & - & 3 & - & 3 & - & - & - & - \\
\hline & 8 & 0.92 & 23 & 13 & 16 & 5 & 19 & 13 & 50 & 49 & 100 & 39 & 100 & 19 \\
\hline & 10 & 1.00 & 76 & 87 & 84 & 95 & 81 & 84 & 50 & 48 & - & 61 & - & 81 \\
\hline & 12 & 1.06 & 1 & - & - & - & - & - & - & - & - & - & - & - \\
\hline \multirow[t]{6}{*}{$M d h-1$} & 4 & 0.63 & 1 & 2 & 2 & 5 & 3 & - & - & - & - & - & - & - \\
\hline & 6 & 0.80 & 30 & 32 & 40 & 26 & 23 & 40 & - & - & - & - & - & - \\
\hline & 8 & 0.89 & 3 & - & 1 & - & 1 & - & - & 1 & - & - & - & - \\
\hline & 10 & 1.00 & 66 & 66 & 57 & 69 & 73 & 60 & 50 & 49 & 50 & 50 & 50 & 50 \\
\hline & 12 & 1.13 & - & - & - & - & - & - & - & 1 & - & - & - & - \\
\hline & 14 & 1.16 & - & - & - & - & - & - & 50 & 49 & 50 & 50 & 50 & 50 \\
\hline \multirow[t]{5}{*}{$M d h-2$} & 6 & 0.79 & 2 & 1 & 3 & 2 & 1 & - & - & - & - & - & - & - \\
\hline & 8 & 0.85 & - & - & - & 1 & - & - & 50 & 54 & 50 & 50 & 100 & 77 \\
\hline & 10 & 1.00 & 97 & 99 & 95 & 95 & 99 & 100 & 50 & 45 & 44 & 44 & - & 23 \\
\hline & 12 & 1.15 & 1 & - & - & - & - & - & - & - & - & - & - & - \\
\hline & 14 & 1.27 & 1 & - & 2 & 2 & - & - & - & 1 & 6 & 6 & - & - \\
\hline \multirow[t]{3}{*}{$I d h$} & 8 & 0.74 & - & - & - & - & 1 & - & - & - & - & - & - & - \\
\hline & 10 & 1.00 & 99 & 100 & 92 & 98 & 99 & 100 & 50 & 96 & 100 & 100 & 100 & 100 \\
\hline & 12 & 1.23 & 1 & - & 8 & 2 & - & - & 50 & 4 & - & - & - & - \\
\hline \multirow[t]{5}{*}{$6 P g d h$} & 6 & 0.64 & - & - & - & - & - & - & - & 2 & - & - & 50 & 27 \\
\hline & 8 & 0.76 & 5 & 3 & 2 & 7 & 4 & 7 & - & 47 & 50 & 22 & - & 33 \\
\hline & 10 & 1.00 & 57 & 57 & 59 & 51 & 69 & 57 & 50 & 2 & - & 28 & - & - \\
\hline & 12 & 1.24 & 36 & 34 & 31 & 38 & 27 & 36 & 50 & 49 & 50 & 50 & 50 & 50 \\
\hline & 14 & 1.56 & 2 & 4 & 8 & 4 & - & - & - & - & - & - & - & - \\
\hline \multirow[t]{6}{*}{$P g m$} & 6 & 0.68 & 3 & 4 & - & - & - & - & - & 15 & 5 & - & - & 6 \\
\hline & 8 & 0.80 & 12 & 5 & 3 & 7 & 10 & 10 & 50 & 57 & 94 & 100 & - & 56 \\
\hline & 10 & 1.00 & 61 & 57 & 64 & 64 & 47 & 63 & - & 1 & - & - & 50 & 6 \\
\hline & 12 & 1.17 & 4 & 9 & 10 & 12 & 13 & 3 & 50 & 26 & - & - & 50 & 31 \\
\hline & 14 & 1.33 & 18 & 21 & 21 & 16 & 27 & 23 & - & 1 & 1 & - & - & - \\
\hline & 16 & 1.48 & 2 & 4 & 2 & 1 & 3 & - & - & - & - & - & - & - \\
\hline \multirow[t]{4}{*}{$P g i$} & 8 & 0.52 & 2 & 1 & - & 2 & 1 & - & - & - & - & - & - & - \\
\hline & 10 & 1.00 & 76 & 72 & 69 & 69 & 66 & 73 & 50 & 4 & 2 & 6 & 50 & 50 \\
\hline & 12 & 1.53 & 22 & 26 & 29 & 29 & 30 & 27 & 50 & 95 & 98 & 94 & 50 & 50 \\
\hline & 14 & 2.23 & - & 1 & 2 & - & 3 & - & - & 1 & - & - & - & - \\
\hline \multirow[t]{5}{*}{ Est-d } & 4 & 0.59 & - & - & - & 1 & - & - & - & - & - & - & - & - \\
\hline & 6 & 0.79 & 2 & 3 & 1 & 2 & - & - & - & - & - & - & - & - \\
\hline & 8 & 0.90 & - & 1 & 1 & - & - & - & - & 1 & - & - & 50 & 2 \\
\hline & 10 & 1.00 & 98 & 96 & 97 & 97 & 99 & 100 & 100 & 99 & 100 & 100 & 50 & 98 \\
\hline & 12 & 1.12 & - & - & 1 & - & 1 & - & - & - & - & - & - & - \\
\hline \multirow[t]{7}{*}{ Ocdh } & 2 & 0.48 & 3 & 4 & 7 & 2 & 3 & - & - & - & - & 6 & - & - \\
\hline & 4 & 0.69 & 22 & 35 & 38 & 52 & 11 & 53 & - & 22 & 8 & - & 45 & 8 \\
\hline & 6 & 0.76 & 2 & - & - & - & - & - & - & - & - & - & - & - \\
\hline & 8 & 0.90 & - & - & - & - & - & - & - & - & 2 & - & - & - \\
\hline & 10 & 1.00 & 69 & 59 & 51 & 45 & 86 & 47 & 100 & 77 & 51 & 61 & 55 & 65 \\
\hline & 12 & 1.12 & - & - & 1 & - & - & - & - & - & - & - & - & - \\
\hline & 14 & 1.26 & 4 & 2 & 3 & 1 & - & - & - & 1 & 39 & 33 & - & 27 \\
\hline Lap & 4 & 0.80 & 7 & 13 & 8 & 9 & 6 & 13 & - & - & - & - & - & 4 \\
\hline & 6 & 0.86 & 12 & 8 & 10 & 28 & 20 & 20 & 50 & 49 & 50 & 50 & 68 & 46 \\
\hline & 8 & 0.93 & 17 & 12 & 18 & 9 & 23 & 20 & - & 1 & - & - & - & - \\
\hline & 10 & 1.00 & 35 & 39 & 30 & 34 & 26 & 27 & - & 50 & 47 & 44 & 32 & 50 \\
\hline & 12 & 1.06 & 29 & 28 & 34 & 20 & 25 & 20 & 50 & - & 3 & 6 & - & - \\
\hline$H k$ & 4 & 0.70 & - & 1 & - & - & - & - & - & - & - & - & - & - \\
\hline & 6 & 0.72 & 1 & 3 & 1 & 1 & 1 & - & - & 1 & 1 & - & - & 10 \\
\hline & 8 & 0.89 & 3 & 9 & 3 & 6 & 1 & 7 & 50 & 31 & 10 & 33 & 100 & 79 \\
\hline & 10 & 1.00 & 94 & 85 & 96 & 90 & 96 & 90 & 50 & 68 & 89 & 67 & - & 11 \\
\hline & 12 & 1.09 & 2 & 2 & - & 3 & 2 & 3 & - & - & - & - & - & - \\
\hline
\end{tabular}


Table 2 (continued)

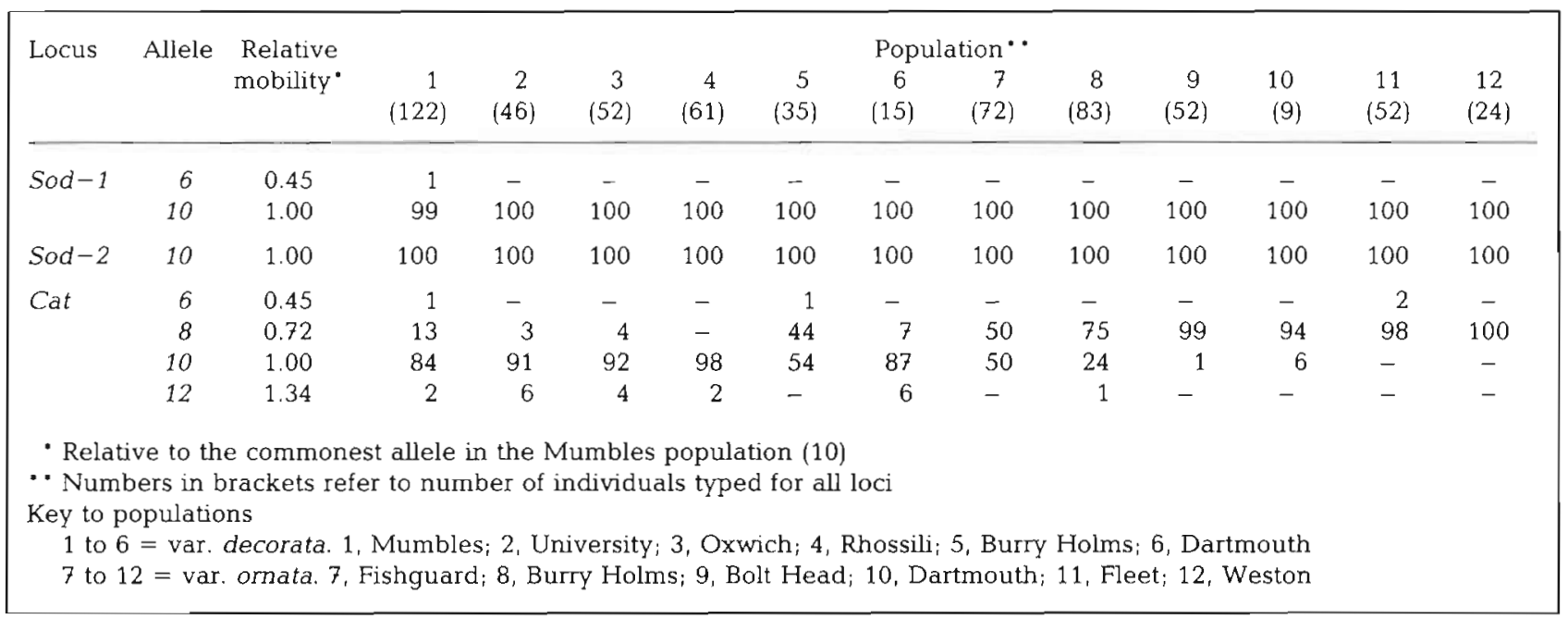

\section{IDENTITY}

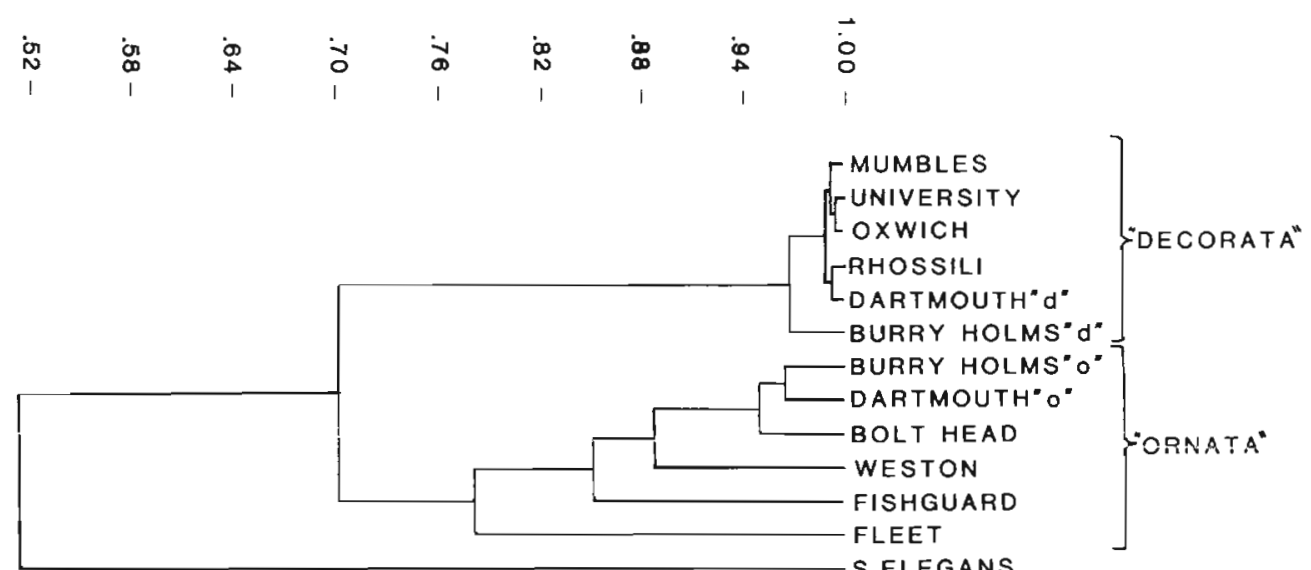

Fig. 2. Sagartia troglodytes. Phenogram of Nei's I between populations. \% standard deviation (Fitch \& Margoliash 1967) $=8.87$;

Farris (1972) ' $F$ ' $=3.00$

Table 3. Summary results of studies of reproductive biology on the var. decorata population at Mumbles and the var. ornata population at Burry Holms

\begin{tabular}{|c|c|}
\hline Var. decorata & Var. ornata \\
\hline $\begin{array}{l}\text { Population gonochoric, sex ratio roughly } \\
\text { equal }\end{array}$ & All individuals female \\
\hline $\begin{array}{l}\text { Peak gonad development Dec to Apr } \\
\text { spawning Mar/Apr }\end{array}$ & (Data not available) \\
\hline $\begin{array}{l}\text { Mean diameter of 'mature' eggs }=119 \mu \mathrm{m} \\
\text { (gonad squashes) }\end{array}$ & $\begin{array}{l}\text { Mean diameter of 'mature' eggs }=114 \mu \mathrm{m} \\
\text { (gonad squashes) }\end{array}$ \\
\hline $\begin{array}{l}\text { Mean no, eggs per ovary }=102 \text { (up to } 24 \\
\text { ovaries per individual) }\end{array}$ & $\begin{array}{l}\text { Mean no. eggs per ovary }=98 \text { (up to } 24 \\
\text { ovaries per individual) }\end{array}$ \\
\hline $\begin{array}{l}\text { No evidence of budding, fission or lacera- } \\
\text { tion }\end{array}$ & $\begin{array}{l}\text { No evidence of budding, fission or lacera- } \\
\text { tion }\end{array}$ \\
\hline No larvae or actinulae found brooded & $\begin{array}{l}\text { Small actinulae found brooded in } 60 \text { to } \\
100 \% \text { of individuals (mean brood size }= \\
12, \mathrm{SD}=12.6 \text { ) }\end{array}$ \\
\hline
\end{tabular}


March and into April as mean sea temperature rises from the winter minimum in February; immediately after spawning primary oocytes and spermatogonia proliferate in the reconstituted gonads; development of pre-vitellogenic oocytes and testis tubules containing spermatocytes and spermatids proceeds throughout the summer; final maturation of ovaries containing only mature eggs and testis with mature sperm occurs during December to February. The pattern is typical of northern arctic/boreal species near the southern part of their range (Orton 1920), and egg size and fecundity suggest an oviparous reproductive style with planktonic development (Thorson 1950, Chia 1976). There is no evidence of any asexual mode of propagation. The data for the ornata population can only be viewed comparatively with those for decorata. During the period of maximum gonad development in decorata all ornata individuals observed (38) were female. No evidence of spawning during this period was found but, although most individuals possessed vitellogenic oocytes, only 2 individuals had large mature oocytes in their ovaries. Planula larvae were found only in 2 individuals in late March, but most individuals throughout the period studied were brooding small actinulae (up to the 24 -tentacle stage). Mean number of actinulae per brood increased from 3.1 ( $\mathrm{SD}=2.2$ ) in January to 21.6 (SD $=16.1$ ) in April. Finally, in all 19 broods typed electrophoretically, there was no evidence of segregation of alleles within the broods at loci heterozygous in the brooding adult (mean brood size tested $=7.8$, all adults being heterozygous at 4,5 or 6 loci\}.

\section{DISCUSSION}

The combination of electrophoretic, chromosomal and reproductive information presented here indicate beyond doubt that the varieties decorata and ornata should be regarded as separate species. To comply with the rules of zoological nomenclature var. decorata retains the species name Sagartia troglodytes (Price) and var. ornata is restored to species status as Sagartia ornata as originally described by Holdsworth (in Gosse 1860). The individuals reportedly intermediate between the 2 varieties are extremely unlikely to be true hybrids and must be seen as a consequence of the high, and possibly overlapping, variability of the 2 species.

The position in Sagartia troglodytes, as it is defined above, appears fairly clear. Around the coasts of SW Britain the species consists of populations which are highly variable morphologically and genetically and which occupy most, but not all, of the habitats traditionally described for the species. Populations have maximal genotypic diversity, suggesting that no asexual mechanisms are utilised, which is supported by the reproductive analysis and the fact that all individuals are regularly hexamerous in structure. All polymorphic loci show good fits to Hardy-Weinberg predictions of random out-crossing, and observed heterozygosity levels suggest no significant inbreeding effects. This all suggests that the observed seasonal gonochoric oviparous style of reproduction is the only style employed. and is effective both locally in maintaining genetic diversity and also in maintaining gene flow between geographically separated populations, as shown by their high genetic identity estimates. Whether this picture is typical of the species throughout its range is difficult to ascertain in view of the previous reports of hermaphroditism and viviparity (Gosse 1860, Stephenson 1935). Stephenson (1929) had earlier reported viviparity in var. ornata but failed to find it in var. decorata. The 2 previous studies devoted expressly to the species (Nyholm 1943, Riemann-Zürneck 1969), from their descriptions, were probably working with var. decorata. Both describe it as gonochoric and oviparous with a planktonic larval stage.

The position in Sagartia ornata is more complicated. The species is less variable morphologically than $S$. troglodytes, and also genetically in terms of mean alleles per locus (overall mean of 2.0 compared to 3.1 for $S$. troglodytes) and genotypic diversity, but is as variable in terms of \% loci polymorphic (62 to $61 \%$ ) and mean individual heterozygosity ( 0.47 to 0.27 ), although the latter 2 parameters are greatly increased by the levels of 'fixed heterozygosity' seen in all 6 populations.

Populations consist of a number of clones which are closely related genetically, but which show large divergence from other populations $(\overline{\mathrm{I}}=0.84)$. The source of the clones is obviously the brooded young as no other method of asexual propagation, such as fission or laceration, has been observed (or previously recorded), although how these broods are produced is still unclear. A similar position has been noted in Actinia equina (Orr et al. 1982) and A. tenebrosa (Black \& Johnson 1979), and Rossi (1971) recorded the continued production of brooded young in isolated individuals of Cereus pedunculatus for up to 13 mo. Black \& Johnson's work successfully refuted ideas of a sexual origin of the broods with post-fertilisation selection (Carter \& Thorp 1979) or re-entry by larvae of identical adults (Ottaway \& Kirby 1975), but reserved judgement on the asexual method used. Orr et al., however, concluded that a form of internal budding based on the principle of somatic embryogenesis (Polteva 1963) was the most likely process. Finally Rossi $(1971,1975)$ suggested apomictic parthenogenesis, a conclusion also favoured more recently for $A$. equina by Brace \& Quicke (1986) and for both A. equina and C. pedunculatus by Schäfer (1981). The present study favours some form of parthenogenesis as the explanation in Sargatia ornata because of the all-female nature of 
populations and the maintenance of functional ovaries in the (suspected) absence of sexual reproduction (see below). Additionally the common association of polyploidy with parthenogenesis in animals (Suomalainen 1961, White 1973) is suggestive.

Sexual reproduction, or any other process involving recombination, appears to be non-existent or rare as evidenced by: the absence of segregation within broods; the lack of evidence of gene dosage effects in the polyploid phenotype; the absolute identity, at some loci, of all genotypes within each population; the only genotype observed at the Mdh-1 locus in all populations is the 10/14 heterozygote; and the extreme departures from random mating expectations of genotype frequencies and heterozygosity levels. Also, gene flow between populations appears to be extremely restricted suggesting poor dispersal of progeny (probably by transport of actinulae rather than by planktonic larvae). All of this suggests localised proliferation, by parthenogenetic production of brooded young, from very few (even one) founding individuals from rare colonisation events or localised selection of more frequent colonists. Although there is a possibility that Sagartia ornata is able to reproduce sexually, the fact that no males were detected in any of the material studied, and the lack of putative recombinant types for the allozyme loci, make our assumption that $S$. ornata is an obligate parthenogen a reasonable one.

That parthenogenesis is widespread amongst animal groups, and that it is often associated with marginal habitats resulting in 'geographic parthenogenesis' is accepted (Vandel 1931, Suomalainen et al. 1976, Glesener \& Tilman 1978, Lynch 1984). Explanations for the success of parthenogenesis in such unstable and environmentally demanding habitats centre on the greater colonising ability of asexual individuals because of their relief from the problems of mating and the 'cost of meiosis' (Williams 1975, Maynard-Smith 1978) and/or the possession of general purpose genotypes (Lynch 1984). The lack of success in more stable, 'biotically complex' habitats has been explained by the competitive abilities of sexual individuals due to their enhanced flexibility in terms of time (Glesener \& Tilman 1978) or present variability (Bell's 'tangled bank' model, 1982). However, Jackson (1985) has argued the reverse for clonality in benthic marine invertebrates. Sagartia ornata certainly has extended its range into marginal habitats compared to $S$. troglodytes; both the Fleet and Fishguard populations are subjected to daily fluctuations of salinity and coincidentally have the most restricted genotypic variability. S. ornata also shows much higher levels of individual heterozygosity, if that can be taken as a measure of the flexibility of genotypes. An example of greater physiological flexibility of clonal over aclonal species of sea anemones has already been shown in the case of Haliplanella lineata (clonal) versus Diadumene leucolena (aclonal) (Shick \& Dowse 1985).

The tetraploid state of Sagartia ornata is not hard to accommodate if it is an obligate parthenogen. The association of polyploidy and parthenogenesis (Suomalainen 1950) has been explained as a consequence of asexual reproduction removing most of the barriers to polyploidisation in sexual species, such as meiotic irregularities, disruption of sex-determining mechanisms, production of aneuploid gametes and disruption by back-crosses (White 1973), and conversely by the fact that polyploidy may aid the establishment of parthenogenesis by providing additional sites for the production of new allelic combinations.

Finally, on the subject of the origins of such species, Suomalainen (1961) considered that the closely related 'overall genotypes' within populations of the tetraploid weevil Otiorrhynchus scaber and the occurrence of 3 loci monomorphic for a heterozygous genotype throughout the race indicated a monophyletic origin, with localised differentiation caused by selection on mutations of the original ancestral genotype. White (1973), however, declared that such patterns were due to polyphyletic origins by multiple hybridisations between ancestral species. Additionally, the occurrence of 'fixed heterozygosity' patterns in some plant species has been put down to their hybrid origin (Roose \& Gottlieb 1976) and likewise, the elevated heterozygosity of parthenogens is a result of hybrid origins according to Lynch (1984).

Sagartia ornata could: thus, be considered a collection of obligately parthenogenetic clones arising from hybridisation events between $S$. troglodytes and another, perhaps extinct, species or between isolated and genetically different populations of $S$. troglodytes, which have enabled establishment in more demanding rocky shore and brackish water habitats outside the ancestral species' range.

Acknowledgements. We are grateful to Mr A. I. Yaseen for assistance with chromosome preparations. P. Shaw acknowledges the tenure of a N.E.R.C. research studentship.

\section{LITERATURE CITED}

Avise, J. C., Smith, M. H., Ayala, F. J. (1975). Adaptive differentiation with little genic change between two native California minnows. Evolution 29: 411-426

Ayala, F. J., Hedgecock, D., Zumwalt, G., Valentine, J. W. (1973). Genetic variation in Tridacna maxima, an ecological analog of some unsuccessful evolutionary lineages. Evolution 27: 177-191

Ayre, D. J. (1983). The effects of asexual reproduction and inter-genotypic aggression on the genotypic structure of populations of the sea anemone Actinia tenebrosa. Oecologia (Berl.) 57: 158-165

Bell, G. (1982). The masterpiece of nature: the evolution and genetics of sexuality. Univ. California Press, Berkeley 
Black, R., Johnson, M. S. (1979). Asexual viviparity and population genetics of Actinia tenebrosa. Mar. Biol. 53: 27-31

Brace, R. C., Quicke, D. L. J. (1986). Dynamics of colonization by the beadlet anemone, Actinia equina. J. mar. biol. Ass. U. K. 66: 21-47

Bucklin, A., Hedgecock, D. (1982). Biochemical genetic evidence for a third species of Metridium (Coelenterata: Actiniaria). Mar. Biol. 66: 1-7

Carter, M. A., Thorp, C. H. (1979). The reproduction of Actinia equina L. var. mesembryanthemum. J. mar. biol. Ass. U. K. 59: $989-1001$

Chia, F. S. (1976). Sea anemone reproduction: patterns and adaptive radiations. In: G. O. Mackie (ed.) Coelenterate ecology and behaviour. Plenum Press, New York, p. 261-270

Farris, J. S. (1972). Estimating phylogenetic trees from distance matrices. Am. Nat. 106: 645-668

Fitch, W. M., Margoliash, E. (1967). Construction of phylogenetic trees. Science 155: 279-284

Glesener, R. R., Tilman, D. (1978). Sexuality and the components of environmental uncertainty: clues from geographic parthenogenesis in terrestrial animals. Am. Nat. 112: 659-673

Gosse, P. H. (1860). A history of the British sea anemones and corals. Van Voorst, London

Harris, H., Hopkinson, D. A. (1976). Handbook of enzyme electrophoresis in human genetics. North-Holland, Amsterdam

Hoffmann, R. J. (1976). Genetics and asexual reproduction of the sea anemone Metridium senile. Biol. Bull. mar. biol. Lab., Woods Hole 151: 478-488

Jackson, J. B. C. (1985). Distribution and ecology of clonal and aclonal benthic invertebrates. In: Jackson, J. B. C., Buss, L. W., Cook, R. E. (ed.) Population biology and evolution of clonal organisms. Yale Univ. Press, New Haven, p. 297-356

Levene, H. (1949). On a matching problem arising in genetics. Ann. math. Statist 20: 91-94

Lynch, M. (1984). Destabilising hybridisation, general-purpose genotypes and geographic parthenogenesis. Q. Rev. Biol. 59: 257-290

Manuel, R. L. (1981). British Anthozoa. Linnean Society, London

Maynard Smith, J. (1978). The evolution of sex. Cambridge Univ. Press, Cambridge

Nei, M. (1972). Genetic distance between natural populations. Am. Nat. 106: 283-292

Nei, M. (1978). Estimation of average heterozygosity and genetic distance from a small number of individuals. Genetics 89: 583-590

Nyholm, K-G. (1943). Zur Entwicklung und Entwicklungsbiologie der Ceriantharien und Aktinien. Zool. Bidr. Uppsala 22: 87-248

Orr, J., Thorpe, J. P., Carter, M. A. (1982). Biochemical genetic confurmation of the asexual reproduction of brooded offspring in the sea anemone Actinia equina. Mar Ecol. Prog. Ser. 7: 227-229

Orton, J. H. (1920). Sea temperature, breeding and distribution in marine animals. J. mar biol. Ass. U. K. 12: 339-366

Ottaway, J. R., Kirby, D. C. (1975). Genetic relationships between brooding and brooded Actinia tenebrosa. Nature, Lond. 255: 221-223

Polteva, D. G. (1963). Regeneration and somatic embryogenesis of Actinia equina in different stages of ontogenetic development. Acta. biol. Hung. 14: 199-208

Poulik, M. D. (1957). Starch gel electrophoresis in a discontinuous system of buffers. Nature, Lond. 180: 1477-1479
Quicke, D. L. J., Brace, R. C. (1983). Phenotypic and genotypic spacing within an aggregation of the anemone, Actinia equina. J. mar. biol. Ass. U. K. 63: 493-515

Rahat, A., Rahat, M., Searle, J. B. (1985). A simple method for the preparation of hydra chromosome spreads: introducing chromosome counts into hydra taxonomy. Experientia 41: $282-283$

Riemann-Zürneck, K. (1969). Sagartia troglodytes (Anthozoa) Biologie und Morphologie einer schlickbewohnenden Aktinie. Veröff. Inst. Meeresforsch. Bremerhaven 12: $169-230$

Roose, M. L., Gottlieb, L. D. (1976). Genetic and biochemical consequences of polyploidy in Tragopogon. Evolution 30: $818-830$

Rossi, L. (1971). Thelytochous parthenogenesis in Cereus pedunculatus (Actiniaria). Experientia 27:349-351

Rossi, L. (1975). Sexual races in Cereus pedunculatus. Pubbl. Staz. zool. Napoli 39: 461-470

Schäfer, W. (1981). Fortpflanzung und Sexualität von Cereus pedunculatus und Actinia equina (Anthozoa, Actiniaria). Helgoländer Meeresunters. 34: 451-461

Schmidt, H. (1972). Prodromus zu einer Monographie der mediterranean Aktinien. Zoologica Stuttg. 121: 1-146

Shaw, C. R., Prasad, R. (1970). Starch gel electrophoresis of enzymes - a compilation of recipes. Biochem. Genet. 4: $297-320$

Shick, M. J., Dowse, H. B. (1985). Genetic basis of physiological variation in natural populations of sea anemones: intraand interclonal analyses of variance. In: Gibbs, P. E. (ed.) Proceedings 19th European Marine Biology Symposium. Cambridge Univ. Press, Cambridge, p. 465-479

Shick, M. J., Lamb, A. N. (1977). Asexual reproduction and population structure in the colonizing sea anemone Haliplanella luciae. Biol. Bull. mar. biol. Lab., Woods Hole 153 604-617

Sneath, R. H. A., Sokal, R. R. (1973). Numerical taxonomy. W. H. Freeman and Co., San Francisco

Stephenson, T A. (1929). On methods of reproduction as specific characters. J. mar. biol. Ass. U. K. 16: 131-172

Stephenson, T. A. (1935). The British sea anemones, Vol. 2. The Ray Society, London

Suomalainen, E. (1950). Parthenogenesis in animals. Adv Genet. 3: 193-253

Suomalainen, E. (1961). On morphological differences and evolution of different polyploid parthenogenetic weevil populations. Hereditas 47: 309-341

Suomalainen, E., Saura, A., Lokki, J. (1976). Evolution of partherogenetic insects. Evol. Biol. 9: 209-257

Swofford, D. L., Selander, R. B. (1981). BIOSYS-1: a FORTRAN program for the comprehensive analysis of electrophoretic data in population genetics and systematics. J. Hered. 72: $281-283$

Thorpe, J. P. (1982). The molecular clock hypothesis: biochemical evolution, genetic differentiation and systematics. Ann. Rev. Ecol. Syst. 13: 139-168

Thorson, G. (1950). Reproductive and larval ecology of marine bottom invertebrates. Biol. Rev. 25: 1-45

Tracey, M. L., Bellet, N. F., Gravem, C. D. (1975). Excess allozyme homozygosity and breeding structure in the mussel Mytilus califormianus. Mar. Biol. 32: 303-311

Vandel, A. (1931). La parthenogénèse. G. Doin, Paris

White, M. J. D. (1973). Animal cytology and evolution. Cambridge Univ. Press, Cambridge

Williams, G. C. (1975). Sex and evolution. Princeton Univ. Press, Princeton 